Crop Breeding and Applied Biotechnology 14: 256-260, 2014

Brazilian Society of Plant Breeding. Printed in Brazil

NOTE

http://dx.doi.org/10.1590/1984-70332014v14n4n40

\title{
Inheritance of different fiber colors in cotton (Gossypium barbadense L.)
}

Luiz Paulo de Carvalho ${ }^{1 *}$, Francisco José Correia Farias ${ }^{1}$, Marleide Magalhães de Andrade Lima ${ }^{1}$ and Josiane Isabela da Silva Rodrigues ${ }^{1}$

Received 27 February 2014

Accepted 29 April 2014

\begin{abstract}
Most of cotton (Gossypium hirsutum) fibers produced in the world are white, in spite of the lint and fiber of tetraploid cottons (G. barbadense), exhibiting various shades of green and brown. Cotton fiber color is a genetically inherited trait resulting from the presence of pigments intermingled with cellulose. Inheritance of fiber color is relatively simple, with high heritability, but in wild accessions it is still unknown. The objective of this study was to determine the inheritance of fiber color in $\mathrm{G}$. barbadense accessions representing different shades of brown. We crossed wild $\mathrm{G}$. barbadense accessions and $\mathrm{G}$. hirsutum cultivars (with white fiber) and obtained the $F_{2}$ generations, and $B C_{1}$ and $B C_{2}$ backcrosses. It may be concluded that fiber color is controlled by one gene, with partial dominance of the brown color over white, except for the grayish color of the PI 435267 accession, which showed the white to be partially dominant.
\end{abstract}

Key words: Colored lint, cotton, heredity.

\section{INTRODUCTION}

Nearly all cotton fibers produced in the world are white; however, lint and fiber of tetraploid cottons occur in colors ranging from white to various shades of green and brown. In addition, Gossypium hirsutum L. typically has white fiber and $G$. barbadense L. frequently has cream color (Percy and Kohel 1999). The color of cotton fiber is the result of the presence of pigments intermingled with cellulose. It is a genetically inherited characteristic resulting in different shades of green and brown (Dickerson et al. 1999). Cotton with colored fiber has been grown since ancient times, as shown by excavations made in Huaca Prieta, Peru, dating back to 2500 B.C. Analyses of cloth fragments from this era show that they were probably primitive forms of $G$. barbadense (Chaudhry 1992). Fiber fragments were found in the colors blue, purple, pink, brown, green, bronze, and red. Some of these colors for cotton still exist, but others have disappeared and did not come to be described in the botanical literature (Chaudhry 1992). In some germplasm banks, one may find accessions with colored fiber in shades of brown (from dark chocolate brown to cream colored), yellowish, grayish, orangish, and purplish in G. barbadense. Many other wild species of the genus Gossypium, most of them diploid, have colored lint, a large part in brown tones. Fryxell (1984) lists these species and their respective colors of fiber or lint. Colored fiber cotton has been grown and used in textile products from indigenous populations of the Americas for centuries (Vreeland Jr 1987).

Fiber color is genetically controlled. In general, inheritance of fiber color is relatively simple and has high heritability. Some genes responsible for fiber color were reported by Ware (1932), Harland (1935) and Kohel (1985).

The green color of the fiber and the lint is brought about by a dominant mutant $\mathrm{Lg}$, reported in G. hirsutum (Ware 1932). An allelic variant of $\mathrm{Lg}$, in which only the lint remains green and the fiber is white, was determined and designated $\operatorname{Lg}^{\mathrm{f}}$ (Kohel 1985). According to the author, the green color of the fiber varies according to the genetic base it has. In certain cases, $\operatorname{LgLg}$ draws near the expression associated with Lglg, and the latter is sometimes difficult to distinguish from lglg. Harland (1935) determined that the brown color of the fiber was conditioned on two independent loci, Lc1 and Lc2, in G. hirsutum and G. barbadense. A third variant in brown coloring, designated dirty white (Dw) has expression equivalent to Lc 1 and was transferred from $G$. raimondii to $G$. hirsutum, according to Rhine (1960).

${ }^{1}$ Embrapa Algodão, Rua Oswaldo Cruz, 1.143, Bairro Centenário, CP 174, 58.428-095, Campina Grande, PB, Brazil. *E-mail: luiz.carvalho@embrapa.br 
Kohel (1985) mentions four additional loci with dominant alleles in relation to the brown color, denominated Lc3, Lc4, Lc5, and Lc6.

All the colors are developed under the sun after the opening of the cotton bolls (Chaudhry 1992). At first, the fiber is white and, in approximately one week, it assumes the color according to its genotypic constitution. The shades of the colored cotton may vary according to the season of the year and the location, due to climate and soil variations (Dickerson et al. 1999).

According to Backe (1994), due to the low yields and low spinning capacity, colored fiber has not been greatly used for commercial textile purposes. Nevertheless, there is currently growing worldwide interest in the use of clothing made from naturally colored cotton. The brown fiber color in wild G. barbadense may vary from slightly cream to chocolate colored, along with other shades, such as grayish, yellowish, purplish, and orangish.

Embrapa Algodão collected colored cotton materials in the semiarid Brazilian Northeast that exhibited a light brown color, which constituted the Germplasm Bank of mocó cotton. Nevertheless, inheritance of this color has not yet been studied (Freire et al. 1997). Some cultivars with colored fiber have already been introduced (Queiroz et al. 2012). However, the breeding program seeks to transfer some colors of G. barbadense to G. hirsutum L. (with white fiber) for the purpose of obtaining cultivars with new shades of color.

Inheritance of the colors in these wild accessions is still unknown. We aimed to study the inheritance of fiber color in accessions of G. barbadense L. exhibiting different shades of brown. The species G. hirsutum L. with white fiber was used in crosses with G. barbadense L. in studies of inheritance because the aim in breeding is to introgress these genes of G. barbadense in G. hirsutum L., obtaining cultivars with colored fiber.

\section{MATERIAL AND METHODS}

In this study, we used four accessions of $G$. barbadense, with yellowish, grayish, and orangish fiber color from the Banco de Germoplasma Americano, GRIN (Figure 1) and another accession with chocolate brown fiber color. These accessions were sown in the soil in a greenhouse in a 5-m length row for each accession, and cultivars of $G$. hirsutum L. r. latifolium Hutch. with white-colored fiber were sown beside them. The $\mathrm{F}_{1}, \mathrm{~F}_{2}, \mathrm{BC}_{1}$, and $\mathrm{BC}_{2}$ generations were obtained between each one of the accessions with color in the fiber and a cultivar with white fiber. As the accessions of $G$. barbadense had a later cycle in relation to those of $G$. hirsutum, and their flowering occur at different times from each other, more than one cultivar with white fiber were planted and at different times for flowering to coincide. The procedures for the crosses were those routinely used in cotton breeding programs. The $\mathrm{F}_{1}$ seeds obtained were also planted in 5-m rows beside the parental cultivars with white fiber and, at the time of flowering, backcrosses were carried out for both the progenitors to obtain the $\mathrm{BC}_{1}$ and $\mathrm{BC}_{2}$ generations. Part of the flowers was self-pollinated to obtain the $\mathrm{F}_{2}$ generation. At the time of opening of the cotton bolls of the $\mathrm{F}_{1}$ generation, the plants were assessed in regard to fiber color. To assess the $\mathrm{F}_{2}$ and backcross generations, at the opening of the cotton bolls of each plant in each generation, 1 to 2 cotton bolls were harvested, which were placed in paper bags and taken to the laboratory, where visual analysis of color was made, classifying them as white or colored, regardless of the intensity of the color. The samples were also assessed in regard to color using spectroscopy in the visible and near infrared (VIS/NIR) range to better differentiate those slightly colored from the white.The data from the segregating generations thus obtained were then subjected to the $\chi^{2}$ test, verifying the fit with expected genetic proportions.

\section{RESULTS AND DISCUSSION}

Table 1 contains the results of the cross between the accession PI 608352 of G. barbadense of orangish fiber (Figure 1) and the cultivar of G. hirsutum, BRS Aroeira, with white fiber. The fiber of the $F_{1}$ generation had an intermediate color, with the orangish color (Figure 1) partially dominant over white. The $\mathrm{F}_{2}$ generation showed plant segregation of colored fiber and white fiber well fitted to the expected 3:1 proportion according to the $\chi^{2}$ test with a probability of occurrence of $0.50-0.70$. The backcross with the white fiber progenitor BRS Aroeira showed segregation of 1:1 of plants

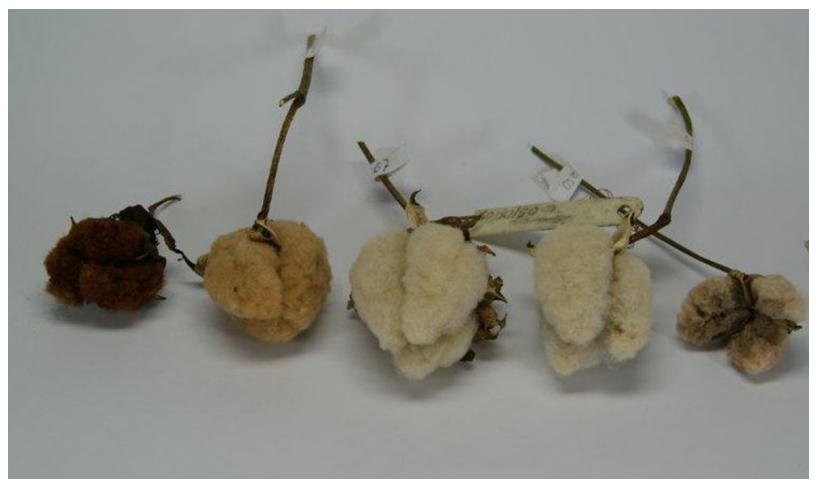

Figure 1. Accessions of Gossypium barbadense used with different fiber colors, from left to right: chocolate brown, orangish (PI 608352), yellowish (PI 528086), grayish (PI 435267), dark brown (PI 435250). 
LP Carvalho et al.

Table 1. Fiber color in the plants of the $F_{1}$ and $F_{2}$ generations and backcrosses

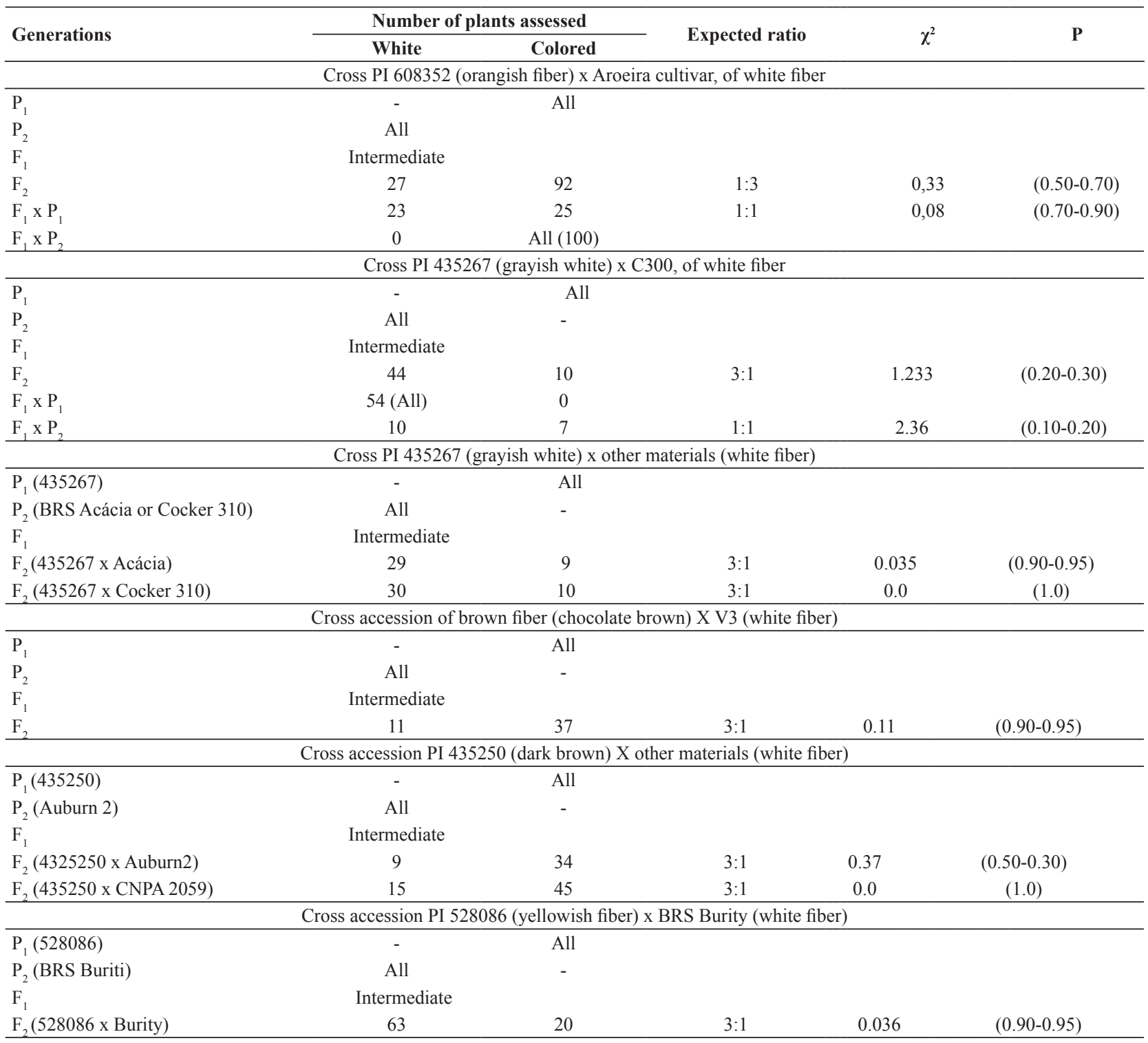

of colored fiber to white fiber, as expected, with a $\chi^{2}$ of high probability of occurrence of $0.70-0.90$. The backcross with the progenitor of colored fiber, for its part, confirmed the action of only one gene controlling the trait upon showing all the plants with colored fiber, which was also expected in the case of the hypothesis being true. Such results are in agreement with those obtained by Wang et al. (2012) upon evaluating the inheritance of colored varieties of cotton. The authors used a complete diallel cross with five varieties of brown color and five varieties of green color and observed that the colors brown and green were governed by a single gene. Brown color showed dominant inheritance, while the green color showed dominant inheritance, incomplete dominance, and recessive characteristics in the different populations studied.

Table 1 shows the results of the cross of the G. barbadense genotype, PI 435267, of grayish white color with other cultivars of white color ('BRS Acácia' and 'Coker $\left.310^{\prime}\right)$. In this case, there is also only one gene involved in the control of this fiber color in the accession 435267, with the difference that the white is partially dominant (Figure 2). The $\mathrm{F}_{2}$ generation showed a ratio of white fiber to colored plants of $3: 1$, with $\chi^{2}=1.233$ and $\mathrm{P}(0.20-0.30)$, in one 


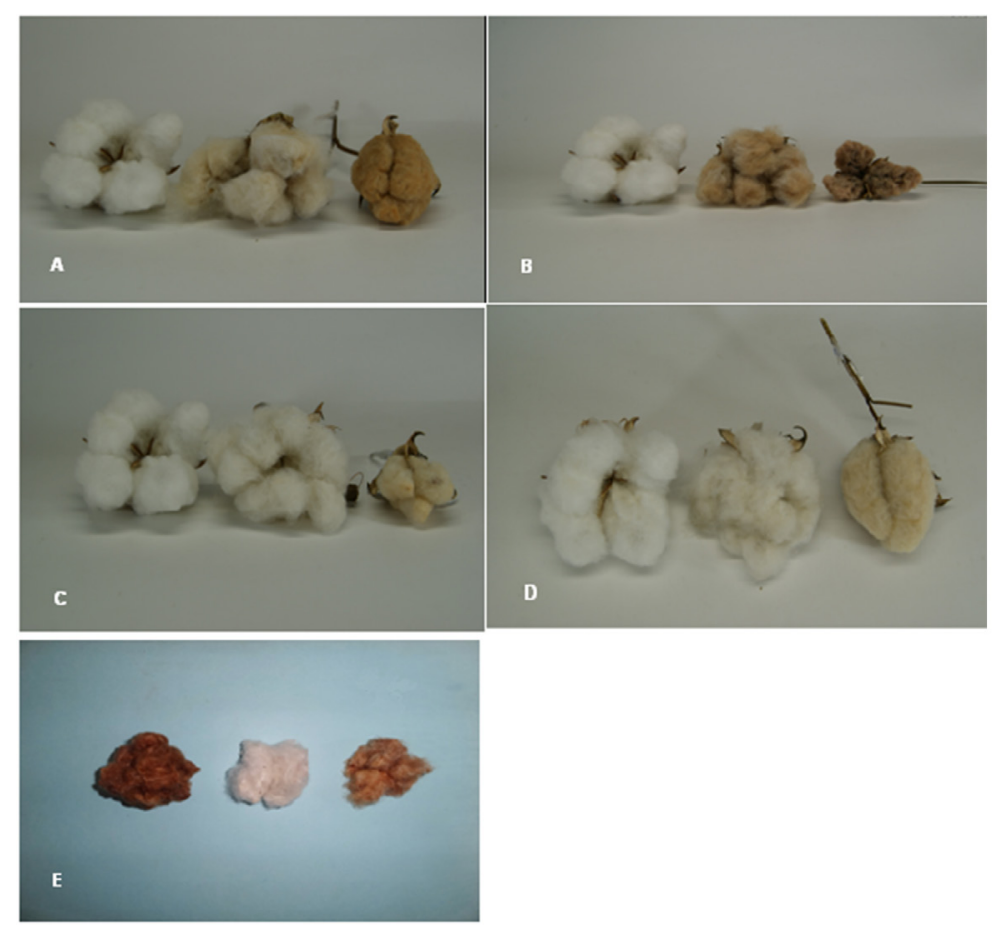

Figure 2. Cotton bolls $\mathrm{F}_{1}$ (center) of the cross of accession of Gossypium barbadense L., PI 835352, of orangish fiber (A); PI 435250, of dark brown fiber (B); PI 528086, of yellowish fiber (C); and PI 435267, of grayish color fiber (D) and chocolate brown color (E) with accessions of G. hirsutum L., of white fiber; In the E photo the $F_{1}$ is at right.

case, and 0.035 and $\mathrm{P}(0.90-0.95)$ in another with perfect fit $\mathrm{P}$ (1.0). The backcross with the progenitor of colored fiber showed segregation fitted to the 1:1 ratio, obtaining $\chi^{2}$ with the probability $\mathrm{P}(0.10-0.20)$. With the progenitor of white fiber, it showed all the plants with white fiber, in accordance with what was expected, considering only one gene involved in manifestation of the trait.

Inheritance of the chocolate brown fiber trait (Figure 2) was assessed based only on the segregation of an $F_{2}$ population between the progenitor of dark brown fiber and another of white fiber denominated V3. In Table 1, it may be seen that one gene controls the expression of the dark brown or chocolate color since the segregation exhibited in the $\mathrm{F}_{2}$ generation fit perfectly with the $3: 1$ ratio, with a high probability of occurrence of the $\chi^{2}$ or $\mathrm{P}(0.90-0.95)$. In Figure $2 \mathrm{E}$ are fiber samples of $\mathrm{F}_{1}$ generation plants showing the parental type, chocolate brown, another plant with white fiber, and one of intermediate fiber color, from left to right. Another dark brown color present in the accession PI 435250 was assessed based on two $\mathrm{F}_{2}$ generations, according to Table 1. Once more, one partially dominant gene (Figure 2) controls the dark brown color of the accession PI 435250. The $\mathrm{F}_{2}$ generation fit perfectly with the $3: 1$ ratio, with a high probability of occurrence of the $\chi^{2}$ or $\mathrm{P}(0.30-0.50)$ in one case, and a perfect fit in the other case, with P (1.0). In the case of the two materials of dark brown or chocolate fiber, it was only possible to assess the $\mathrm{F}_{2}$ generation; it was not possible to make the backcrosses due to the lack of synchronization of the flowering time. The progenitor of dark brown color had quite a late cycle. Table 1 contains the data on segregation of crossing the accession 528086 of yellowish fiber color with another of white fiber, with only the $\mathrm{F}_{2}$ generation being assessed. It may be seen that only one gene regulates the expression of this yellowish color, and the segregation in the $\mathrm{F}_{2}$ generation fits well with the 3:1 proportion, with the yellow color being partially dominant, according to Figure 2.

In Embrapa Algodão, colored cotton materials have already been collected in the semiarid Brazilian Northeast that exhibited a light brown color, which constituted the Germplasm Bank of mocó cotton; however, inheritance of this color has not yet been studied (Freire et al. 1997).

Kohel (1985) assessed accessions of G. hirsutum L. with a brown fiber color and tested them for allelism with genes already known for color, such as the loci $\mathrm{L}_{\mathrm{c} 1}$ and $\mathrm{L}_{\mathrm{c} 2}$ for brown color. Some accessions proved to have genes allelic to $\mathrm{L}_{\mathrm{cl}}$ and others to $\mathrm{L}_{\mathrm{c} 2}$. A phenotype of dark brown fiber color was brought about by an allele in a new locus $\mathrm{L}_{\mathrm{c} 3}$. 
Other loci, $\mathrm{L}_{\mathrm{c} 4}$ and $\mathrm{L}_{\mathrm{c} 5}$ were identified and bring about a light brown color. Probably, the genes of the colors investigated in this study are not the same ones cited by Kohel (1985) due to different species and to the colors that appeared, which have different hues of brown, at times tending to orange, gray, yellow, and dark or chocolate brown, and assessed in this study, as shown in Figure 1.

In addition, this study was carried out for the purpose of observing inheritance of these colors in G. barbadense L. and, consequently, of directing breeding studies already in progress that aim at other cultivars of G. hirsutum L. with the colors exhibited by these genotypes. The results allow us to conclude that the fiber colors analyzed in this study are all governed by one gene, with each color being partially dominant over white, with the exception of the grayish color of the accession PI435267, which showed white as being partially dominant.

\section{Herança de diferentes colorações de fibra em algodoeiro (Gossypium barbadense L.)}

Resumo - A maioria das fibras de algodão (Gossypium hirsutum) produzidas no mundo é de cor branca, apesar do línter e da fibra dos algodões tetraplóides (G. barbadense) apresentarem tonalidades de verde e de marrom. A cor da fibra é uma característica geneticamente herdada, resultante da presença de pigmentos entremeados à celulose. A herança da coloração é relativamente simples e a herdabilidade elevada, porém nos acessos silvestres, esta ainda é desconhecida. Estudou-se a herança da cor de fibra em acessos de G. barbadense que apresentam tonalidades de marrom. Acessos silvestres de G. barbadense e cultivares de G. hirsutum de fibra branca foram cruzados e obtidas as gerações $F_{2}$ e de retrocruzamentos $\left(R C_{1}\right.$ e $\left.R C_{2}\right)$. As cores de fibra são todas governadas por um gene, sendo a cor marrom parcialmente dominante sobre o branco, com exceção da cor acinzentada do material PI 435267 que mostra ser o branco parcialmente dominante.

Palavras-chave: Pluma colorida, algodão, hereditariedade.

\section{REFERENCES}

Chaudhry MR (1992) Natural colors of cotton. ICAC Recorder, Washington, v.10, n.4, p.3-5. (Technical Information Section).

Dickerson DK, Lane EF and Rodrigues DF (1999) Naturally colored cotton: resistance to changes in color and durability when refurbished with selected laundry aids. California State University, Agricultural Technology Institute, Fresno, 38p.

Freire EC, Andrade FP, Farias FJC, Costa JN, Moreira JAN, Vieira RM and Farias RH (1997) Melhoramento do algodão colorido no Nordeste do Brasil. Embrapa CNPA, Campina Grande, 6p. (Embrapa CNPA, Pesquisa em Andamento, 49).

Fryxell PA (1984) Taxonomy and germplasm resources. In Kohel RJ and Lewis CF (eds.) Cotton. Agronomic series No. 24. American Society of Agronomy, Madison, pp. 27-57.

Harland SC (1935) The genetics of cotton. XIV. The inheritance of brown lint in New World cottons. Journal Genetic 31: 27-37.

Kohel RJ (1985) Genetic analysis of fiber color variants in cotton. Crop
Science 25: 793-797.

Percy RG and Kohel RJ (1999) Qualitative genetics. In Smith CW and Cothren JT (eds.) Cotton: Origin, history, technology, and production. John Wiley and Sons, New York, p. 319-360.

Queiroz MA, Barros LM, Carvalho LP, Candeia, JA and Ferraz E (2012) Plant breeding in the semiarid region of Brazil: examples of success. Crop Breeding and Applied Biotechnology 12: 57-66.

Rhyne CL (1960) Linkage studies in Gossypium. II. Altered recombination values in a linkage group of allotetraploid $G$. hirsutum L. as a result of transferred diploid species genes. Genetics 45: 673-681.

Vreeland Jr JM (1987) Coloured cotton: return of the native. International Development Research Center Reports 10: 4-5.

Ware JO (1932) Inheritance of lint colors in upland cotton. Journal of the American Society of Agronomy 24: 550-562.

Wang L, Liu H, Xiao X, Pang Z, Song W, Lu C, Luo C, Liu G, Xu J, Li X and Li X (2012) Studies on hereditary properties of colored cotton in Xinjiang. Agricultural Science \& Technology 13: 541-546. 